UDC 94 (477) (092)

DOI: $10.24919 / 2519-058 \times .7 .131615$

Taras BATIUK,

orcid.org/0000-0003-4159-5226

Ph D hab. (History), Associate Professor of Ukraine's History Department at Ivan Franko Drohobych State Pedagogical University

(Ukraine,Drohobych) tbatyuk@gmail.com

\title{
MYRON KORDUBA'S COOPERATION WITH THE NEWSPAPER «DILO»
}

The article treats the question of Myron Korduba's cooperation with the first Galician Ukrainian daily newspaper "Dilo». The available information, publicistic and critical articles of the scientist on the pages of the newspaper in view has been analyzed. The thematic palette of his publications has been reproduced. The features of the historian's cooperation with "Dilo» throughout the end of the XIX first decade of the $X X$ centuries and, also, in the interwar period have been marked out. The conclusion about the originality Korduba - the journalist's style has been made, as to him the principles in upholding of his position, tolerance in perception of arguments of the opponent, objectivity by interpretation of important social themes were adherent.

Key words: M. Korduba, «Dilo», journalism, publicism, fiction.

Тарас БАТНК, кандидат історичних наук, дочент кафедри історії України Дрогобицького державного педагогічного університету імені Івана Франка (Україна, Дрогобич) tbatyuk@gmail.com

\section{СПІВПРАЦЯ МИРОНА КОРДУБИ ІЗ ГАЗЕТОЮ «ДІЛО»}

Стаття присвячена проблемі співпраці Мирона Кордуби з першою галищькою українською щоденною газетою "Діло». Проаналізовано інформачійні, публічистичні та критичні статті вченого на сторінках видання. Відтворено тематичну палітру його публікацій. Відзначено особливості співробітниитва історика з «Ділом» протягом кіния XIX - першого десятиліття $X X \mathrm{~cm}$., а також у міжвоєнний час. Зроблено висновок про своєрідність стилю Кордуби-журналіста, якому були притаманні принциповість у відстоюванні власної позииіі, толерантність у сприйнятті аргументів опонента, об'єктивність при інтерпретації важливих сочіальних тем.

Ключові слова: М. Кордуба, «Діло», журналістика, публіцистика, белетристика.

The statement of the problem. In the contemporary renaissance of bio-historiographic researches the Korduba studies is one of the most appreciable thematic plots. Thus, more and more often the question of the necessity of overcoming the historical-centrism in studying of the creative inheritance of the outstanding Ukrainian is raised. It goes about the necessity to draw attention not only to the scientific, but also to journalistic, belles-lettres, collection, and other directions of his creative potential's realisation. The author is of the opinion, that Myron Korduba's scientific creativity was densely connected with his journalistic career. After all, it was not infrequent that the periodical press columns contained popular judgements about the purely scientific problems in which the known historian was interested. At the same time, the demands of the national life, which the national periodical press was then pronouncing, made Korduba adjust his professional talent to the challenges of the day. Hence, the author of the article considers a most important problem of the contemporary Korduba studies to be an all-round elaboration of a journalistic com- 
pound of the many-sided activity of that outstanding representative of the Lviv historical school. As the first step of its realisation, the author suggests an attempt a reconstruction of the features of M. Korduba's cooperation with most renowned Ukrainian newspaper «Dilo», in which many outstanding Ukrainian intellectuals of the end of the XIX - first third of the XX century received their journalistic training.

The analysis of the recent researches. The issue of M. Korduba's cooperation with periodicals, along with the aforementioned topicality, has not yet become a subject of at least in any way regular scientific consideration. Actually, by today probably are but two attempts to recreate the journalistic activity of the known Ukrainian study specialist. What is meant is Tetyana Kul'chytska's attempts to find out the features of his cooperation with the Polish periodical editions (Kul'chytska, 2007: 112-136), as well as this article's author's study about M. Korduba as a contributor to the newspaper «Bukovyna» (Batiuk, 2013: 147-151).

The article's purpose is to recreate M. Korduba's many-sided cooperation with the newspaper «Dilo» throughout the first third of the XX century.

The statement of the basic material. The beginnings of M. Korduba's cooperation with the most popular among Galician Ukrainians daily newspaper «Dilo» date back to the end of the XIX century, when the young historian was a student of the Viennese university and informed the Lviv public about the political and cultural life of the imperial capital. His substantial reports, entitled as «The letters from Vienna», were always printed on the first page of the newspaper, which fact testifies both to the importance of the submitted information and their popularity among readers (Korduba, 1897).

M. Korduba's cooperation with «Dilo» went on after his moving in 1900 to the capital of the Bukovyna land, wherein he received a post o the gymnasium professor. Galician Ukrainians at that time were thirsty for the information on the national life of the brotherly population in other regions of Austro-Hungarian empire, so, in a short period of time the young historian becomes a most active Chernivtsi correspondent of the newspaper «Dilo». Thus, in his articles M. Korduba concentrates on the problems of the national struggle of the radical Ukrainian population with the owners of the land alias Romanians and Germans, remarking that «Bukovyna is but Austria in miniature» (Korduba, 1903a: 1).

However, also the internal life of the Ukrainian community of that land often becomes a point of captious attention of the young scientist. Thanks to the fact that M. Korduba mostly contributed his articles anonymously, he could frankly write about the negative sides of the local life of his compatriots (Korduba, 1903b: 1). Here the publicist's craving not only to diagnose the vices of the contemporary to him social life, but also to suggest his own recipes of public recovering are but evident.

Along with the novelties of the local Bukovynian life, the readers of «Dilo» were interested in M. Korduba's travel impressions from his scientific business trips. So, in 1907, on the instruction of the Archeographic Commission o the NTSh, the young scientist throughout several months elaborated Moscow archival collections. Along with purely scientific work, on the instruction of the «Dilo's» editorial board M. Korduba studied the Ukrainian life in the second Russian capital. His observations were generalized in the publicistic sketch «A Letter from Moscow» which was being published throughout several issues of the Lviv newspaper.

First of all, the Chernivtsi historian writes about the difficulties in collecting of the necessary material: «If hitherto I did not write about the Ukrainian community in Moscow, the reason for that was a difficulty with collecting of the necessary data. The number of people, who are interested in the Ukrainian movement, here is very small, and the number of such who could 
tell anything about that movement is even still less. Therefore, all the information I had to collect crumb by crumb and then to stick them together to form something like a picture» (Mykhailovych, 1907, 249: 2).

M. Korduba's observant eye noted the difference between Moscow's and Petersburg's Ukrainian communities which consisted in the absence of «the people at positions», because the centre of business life of the empire was in the northern capital. Those not numerous Ukrainians, the observer stated, who after the first news about liberalisation of the national life in 1905 had joined the Shevchenko Society, later in panic renounced any cultural work during the times of the post-revolutionary reactions.

At the same time, the scientist remarked that «a considerable circle» of Ukrainian youth who studied in Moscow educational institutions also felt a necessity in unification in order to satisfy at least the minimum of national needs. But M. Korduba specified, that from the viewpoint of national consciousness the Ukrainian milieu in Moscow was inexpressive enough. So, students-Ukrainians of the Moscow university, according to the Ukrainian observer, «except only their common territorial background, have nothing to do with the Ukrainian culture» (Mykhailovych, 1907, 249: 2). Among all Moscow higher education establishments, as M. Korduba specified, the Ukrainian youth community of the agricultural institute was the most conscious and active.

Its representatives invited $\mathrm{M}$. Korduba to their session with the request to make a report about cultural and scientific life of their Galician brethren. Certainly, the Chernivtsi historian could not reject their request and spent the whole evening in a companionable circle of youth longing for the news from their brethren from abroad. «It was a beautiful evening and the conversation would go on far after the midnight, if it were not for the last train that departed to Moscow at half past $12 »,-$ so M. Korduba's shared his recollections with the readers of «Dilo» (Mykhailovych, 1907, 249: 3).

The Moscow fellow countrymen liked their guest from Bukovyna, so his meeting with the youth took place again. This time M. Korduba read the lecture «On the cultural and national development of the Ukrainians in Galicia». The glory of the debut speech of the guest from Ukraine had resulted in the fact that to his second lecture a rather large group of youth (over 60 persons) was attracted, as also of the representatives of the elder generation of Ukrainians among whom M. Korduba noticed Ahathangel Krymskyi. And this time again the lecture ended in an interesting discussion of the national progress of Galician Ukrainians which dragged on into the late evening. «In an elevated and pensive mood the guests returned to Moscow by the last train...», - informed M. Korduba his Lviv readers.

Along with the articles of information character, M. Korduba also acquainted that time Galician readers with the novelties of study of Ukraine literature. Suffice it to mention here his resonant critical estimation of the doctor's work of Ivan Dzhydzhora, his colleague by the Lviv historical school. Unlike many other Ukrainian critics (for example, M. Hrushevskyi and M. Vasylenko) who in general approvingly responded to I. Dzhydzhora's work «The economic policy of the Russian government against Ukraine in $1710-1730$ », M. Korduba submitted the work to a sharp criticism. The Chernivtsi scientist in a mocking manner called the aforementioned work of I. Dzhydzhora such which was fully deprived of scientific value. On the pages of «Dilo» he advised his colleague by the historical school «not to spoil paper with groundless guesses and combinations». Specifying on numerous «significant methodical misses», the reviewer rebuked the young author with a discrepancy between the introduction and the conclusions of his doctor's work. To the critic's mind, the suggested by I. Dzhydzhora hypothesis about a considerable de- 
velopment of trade during the times of the Cossack Hetmanate came into a disagreement with the conclusion about the destructive consequences for the Ukrainian lands of a trading regulation during Peter the Great's reforms (Korduba, 1912: 1-3).

It is interesting, that the editorial board of «Dilo» appeared so solidary with their constant author's estimations, that it even refused I. Dzhydzhora in his right to publish a refutable answer. In it the young pupil of M. Hrushevskyi historical school by many examples proved that his senior colleague was extremely partial at criticizing of his doctor's work. The reproaches stated by M. Korduba the young author called «unfair», and the manner in which they had been made he called «inconsiderate». At the end of his respond, with a clear feeling of being offended by his Chernivtsi colleague, I. Dzhydzhora underlined the following: «But all the same, one thing can be expected from M[ister] Korduba: if not a good attitude towards the author so criticized by him, then, in any case, a diligence in the interpretation of the thoughts of the works by other authors with no account for whether they are pleasant for him or not» (Pryshliak, 2004: 542).

In a search for the reasons of such a bitter respond of M. Korduba to the scientific work of his younger colleague and mate by the Lviv scientific milieu, the other of this article shares the view of the contemporary scholar Volodymyr Pryshliak. The Lutsk researcher, pondering on the motivation of M. Korduba's super-critical approach, along with specially professional moments, specifies so: «In that situation, probably, M. Korduba's ambitions «oscillated» and also added to the critique, his elementary envy that, unlike Dzhydzhora, he had not stayed in Lviv, and had to edify pupils in the Chernivtsi gymnasium» (Pryshliak, 2008: 29). The stated observation, to some extent, is confirmed by the reaction to M.Korduba's critical remarks on behalf of the other representatives of the Lviv school. For example, expressing in a letter to I. Dzhydzhora his indignation at the incorrectness of their Chernivtsi colleague, Mykola Zalizniak put to doubt, as he said, the «sewn with too white threads»«suspicious and hardly convincing» criticism of the elder colleague (Pryshliak, 2004: 545).

M. Korduba's cooperation with the newspaper «Dilo» was intensive also in the interwar period. Along with short reports of chronic character, at that time on on the pages of the edition he published larger articles concerning various problems. For example, a substantial sketch «The impressions of a trip to Kiev»», which served as an original report to the Galician community after his visit to the capital of the Soviet Ukraine in 1928. This visit brought about the occasion to invite the Lviv scientist's teacher and the old friend, Mykhalo Hrushevskyi, the then president of the All-Ukrainian Academy of Sciences, to attend a solemn assembly of rendering honours of in commemoration of Volodymyr Antonovych.

With the observant eyes of a skilled journalist M. Korduba at once noticed striking changes in the life of the Dnieper Ukraine. First of all, he could well observe the results of the Ukrainization: the universal use of the Ukrainian language in offices, inscriptions in Ukrainian in Kiev streets, increase of Ukrainian speaking population in the city, and the like. Also, the Galician observer was pleased by many facts displaying the Ukrainization in the field of culture: refined theatrical repertoires, the Ukrainian dubbing-in of foreign films, a great variety of the Ukrainian language printed matter. At the same time, he could not help noticing the impoverishment of the Ukrainian intelligentsia which could not sustain an appropriate standard of life through the modest salary.

But his greatest shock for M. Korduba was total ideologization of all spheres of life of the Soviet society and much stronger intolerance towards dissenters, than it had been during the tsarism time. «And the political relations? - the Galician scientist rhetorically asks. - It may sound paradoxically, as from the point political point of view all there went upside down, one but has to state that in comparison with the pre-war time the political condition of citizens changes least of 
all. The same police system of supervision and importunate, exasperating control of private life, the same insolence of office and government and the lack of protection against that insolence, still more sensible than during the previous regime intolerance to any criticism or, at least, to any different thought» (Korduba, 1928: 8).

Also, at that time M. Korduba acquainted the Ukrainian community of the land with his scientific searches. On the pages of «Dilo», as the most popular by then Ukrainian press tribune, he decided to draw public attention to already half-forgotten national anniversary. namely, the centennial anniversary of the birthday of Feofan Lebedyntsev. For the first time M. Korduba accentuated on the necessity of returning the figure of the founder of the «Kievskaia starina» into the national pantheon on the pages of the newspaper «Dilo» in his study «Contributions to the biography of the forgotten scientist and editor». In that article the researcher made not only his colleagues-historians, but also a wider ranges of Ukrainian intelligentsia to pay attention to the annoying fact of forgetting the pioneer of the Ukrainian humanitarian periodical press; the person, who made public service a matter of all his life (Korduba, 1930: 3).

In the early thirties M. Korduba's cooperation with the newspaper «Dilo» gradually decreases. The appointment of the outstanding study of Ukraine specialist to the historical department of the Warsaw University, where he developed active scientific and pedagogical work that took almost all his free time, was the reason of it. Informing the Ukrainians of the Second Rzeczpospolita of that joyful news, the editorial board of «Dilo» newspaper, at the same time, remarked with grief that its longstanding contributor would be necessitated to considerably limit his cooperation with the Lviv periodical (Ukrainian professors, 1929: 1-2).

The conclusions. So, the analysis of M. Korduba's cooperation with the newspaper «Dilo» allows the author to speak about the outstanding scientist as a talented journalist who with his publicistic pen diagnosed the vices of the contemporary to him society and suggested his own recipes of public recovery. A versatile journalistic repertoire of the renowned representative of the Lviv historical school is too obvious: he arises not only as a journalist-reporter, but also as a talented publicist who skilfully raises important public questions. The multi-topicality of the scientists articles contributed to «Dilo» is impressive. In the focus of attention of Korduba-journalist versatile actual problems of the national existence - political, cultural, and educational, -can be found. The study of the problem topic enabled the author of the given article also to find out many features of M. Korduba's journalistic style. In the author's opinion, inherent to M. Korduba were his adherence to principles in arguing of his own standpoint, tolerance in perception of arguments of his opponent, objectivity at interpretation of important social themes, and - last bit not least - a perpetual work over the improvement of the style of his publicism. Eventually, further special references to M. Korduba's journalistic credo should remain in researchers' view as they will provide opportunities to more fully realize the originality of hiss creative nature.

\section{BIBLIOGRAPHY}

Батюк, 2013 - Батюк Т. Співпраця Мирона Кордуби з газетою «Буковина» // Наукові записки Національного університету «Острозька академія», 2013. Вип. 20. С. 147-151.

Кордуба, 1928 - Кордуба М. Вражіння з поїздки до Києва // Діло. - Львів, 1928. Ч. 84. С. 8.

Кордуба, 1930 - Кордуба М. Причинки до життєпису призабутого ученого і редактора // Діло. 1930. Ч. 9. С. 3.

Кордуба, 1912 - Кордуба М. 3 нашої наукової літератури. Іван Джиджора. Економічна політика російського правительства супроти України в 1710 до 1730 рр. Львів 1912. (Відбитка із Записок наук. тов. ім. Шевченка т. XCVIII, CI, CIII, CV) // Діло. 1912. Ч. 230. С. 1-3.

Кульчицька, 2007 - Кульчицька Т. Мирон Кордуба у польських історичних та суспільнополітичних періодичних виданнях $(1895$ - 1939) // Записки Львівської наукової бібліотеки ім. В. Стефаника. Львів, 2007. Вип. 15. С. 112-136. 
Михайлович, 1907 - Михайлович М. [Кордуба М.]. Лист з Москви // Діло. 1907. Ч. 249. С. 2-3; Ч. 250. С. 2; Ч. 258. С. 2; Ч. 268. С. 2.

Пришляк, 2004 - Пришляк В. Мирон Кордуба та Іван Джиджора: рецензент і автор // До джерел: Збірник наукових праць на пошану О.Купчинського з нагоди його 70-річчя. К.; Львів, 2004. C. 532-554.

Пришляк, 2008 - Пришляк В. Михайло Грушевський та Іван Джиджора: учитель і учень у світлі взаємного листування // Листування Михайла Грушевського. Т. 4: Листування Михайла Грушевського та Івана Джиджори. Київ, Нью-Йорк, Париж, Львів, Торонто: УІТ, ВД «Простір», 2008. - C. 11-47.

Українські професори, 1929 - Українські професори на польських університетах. Дві нові катедри у Варшаві // Діло. 1929. Ч. 53. С. 1-2.

Кордуба, 1897 - [XYZ][Кордуба М.]. Письмо з Ведня // Дело. 1897. Ч. 182. С. 1-2; Ч. 183. C. 1; Ч. 186. С. 1; Ч. 193. С. 1; Ч. 205. С. 1; Ч. 210. C. 1-2.

Кордуба, 1903а - [Кордуба М.]. Політичні відносини на Буковині // Дїло. 1903. Ч. 25. С. 1.

Кордуба, 1903b - [Кордуба М.]. Нова політична акция на Буковині // Дїло. 1903. Ч. 110. С. 1.

\section{REFERENCES}

Batiuk, 2013 - BatiukT. Spivpratsia Myrona Kordubyzhazetoiu «Bukovyna» [Myron Korduba's cooperation with the newspaper «Bukovyna] // Naukovi zapysky Natsionalnoho universytetu «Ostrozka akademiia», 2013. Vyp. 20. Pp. 147-151. [in Ukrainian]

Korduba, 1928 - Korduba M. Vrazhinnia z poizdky do Kyieva [The impressions of a trip to Kiev] // Dilo. - Lviv, 1928. Ch. 84. P. 8. [in Ukrainian]

Korduba, 1930 - Korduba M. Prychynky do zhyttiepysu pryzabutoho uchenoho i redaktora [Contributions to the biography of the forgotten scientist and editor] // Dilo. 1930. Ch. 9. P. 3. [in Ukrainian]

Korduba, 1912 - Korduba M. Z nashoi naukovoi literatury. Ivan Dzhydzhora. Ekonomichna polityka rosiiskoho pravytelstva suproty Ukrainy v 1710 do 1730 rr. Lviv 1912. [From our scientific literature. Ivan Dzhydzhora. The economic policy of the Russian government against Ukraine in 1710 1730] (Vidbytka iz Zapysok nauk. tov. im. Shevchenka t. XCVIII, CI, CIII, CV) // Dilo. 1912. Ch. 230. Pp. 1-3. [in Ukrainian]

Kulchytska, 2007 - Kulchytska T. Myron Korduba u polskykh istorychnykh ta suspilno-politychnykh periodychnykh vydanniakh (1895-1939) [Myron Korduba in the Polish historical and social-political periodicals]// Zapysky Lvivskoi naukovoi biblioteky im. V. Stefanyka. Lviv, 2007. Vyp. 15. Pp. 112-136. [in Ukrainian]

Mykhailovych, 1907 - Mykhailovych M. [Korduba M.]. Lyst z Moskvy [A Letter from Moscow]// Dilo. 1907. Ch. 249. S. 2-3; Ch. 250. S. 2; Ch. 258. S. 2; Ch. 268. S. 2. [in Ukrainian]

Pryshliak, 2004 - Pryshliak V. Myron Korduba ta Ivan Dzhydzhora: retsenzent i avtor [Myron Korduba and Ivan Dzhydzhora: the reviewere and the author] // Do dzherel: Zbirnyk naukovykh prats na poshanu O. Kupchynskoho z nahody yoho 70-richchia. K.; Lviv, 2004. Pp. 532-554. [in Ukrainian]

Pryshliak, 2008 - Pryshliak V. Mykhailo Hrushevskyi ta Ivan Dzhydzhora: uchytel i uchen u svitli vzaiemnoho lystuvannia [Mykhailo Hrushevskyi and Ivan Dzhydzhora: the teacher and the pupil in the light of their correspondence] // Lystuvannia Mykhaila Hrushevskoho. T. 4: Lystuvannia Mykhaila Hrushevskoho ta Ivana Dzhydzhory. Kyiv, Niu-York, Paryzh, Lviv, Toronto: UIT, VD «Prostir», 2008. Pp. 11-47. [in Ukrainian]

Ukrainski profesory, 1929 - Ukrainski profesory na polskykh universytetakh. Dvi novi katedry u Varshavi [Ukrainian professors in Polish universities. Two new departments in Warsaw] // Dilo. 1929. Ch. 53. Pp. 1-2. [in Ukrainian]

Korduba, 1897 - [XYZ] [Korduba M.]. Pysmo z Vednia [A letter from Vienna] // Delo. 1897. Ch. 182. Pp. 1-2; Ch. 183. P. 1; Ch. 186. P. 1; Ch. 193. P. 1; Ch. 205. P. 1; Ch. 210. Pp. 1-2. [in Ukrainian] Korduba, 1903a - [Korduba M.]. Politychni vidnosyny na Bukovyni [The political relations in Bukovyna] // Dilo. 1903. Ch. 25. P. 1. [in Ukrainian]

Korduba, 1903b - [Korduba M.]. Nova politychna aktsyia na Bukovyni [A new political action in Bukovyna] // Dilo. 1903. Ch. 110. P. 1. [in Ukrainian]

Стаття надійшла до редакиї 8.04.2018 p. 